TESTIMONIOS DE AFECTO Y AMISTAD

Revista Atlántica-Mediterránea 22, pp. 11-41

BIBLID [2445-3072 (2020) 22, 1-443]

https://doi.org/10.25267/rev_atl-mediterr_prehist_arqueol_soc.2020.v22.04

\title{
A UN GRAN COLABORADOR
}

\section{Antonio MORENO OLMEDO}

Alcalde de la ciudad de San Fernando (1989-2005)

Antes que nada, quisiera agradecer la oportunidad que se me brinda para que, a través de mis torpes palabras, pueda expresar y exponer mi agradecimiento, tanto institucional como personal a Antonio, por su trabajo, dedicación y honestidad en el mismo. Muchas gracias.

La primera vez que contacto con él, fue en el año 1987, recién elegido concejal, en las elecciones municipales de ese mismo año, y convertirme en aquel momento en el portavoz del primer partido de la oposición; y dado mi interés por las cosas culturales de mi pueblo, fue una iniciación en las actividades que, desde la Delegación de Cultura, se organizaba para nuestra ciudad, y en la que sentía sumo interés por el desarrollo de la misma. Siendo Antonio, uno de los artífices de esas programaciones.

Siempre encontré en él, a una persona cercana, aunque con rictus serio, y sobre todo atento y servicial y muy comprometido con la actividad, a él encomendada. Cuando en 1989 accedo a la alcaldía de la ciudad de San Fernando, tomé la decisión de que también sería Delegado de Cultura, en la que Antonio seguía trabajando, y allí encontré aparte de lo expuesto anteriormente, a un gran colaborador en la búsqueda de nuestro patrimonio histórico y cultural.

A él se debe, la proposición, compra, y puesta al día de archivos y documentos que dieron lugar a que pudiésemos localizar la mesa que presidía la sesiones de la Cortes de la Real Isla de León en 1810. Lo recuerdo, como si fuera ahora mismo.

Con la cara que Antonio entró en mi despacho, con la documentación en la mano. De la descripción de la Exposición de 1910, en el centenario de Las Cortes de nuestra querida ciudad. Y que describía perfectamente dicha mesa, aún tengo grabada la expresión de su cara cuando llegamos a la conclusión que esa mesa la teníamos en la antesala de la Biblioteca Lobo, sin haber sido catalogada.

Un gran descubrimiento. Igualmente, conservo en mi memoria la estampa de un servidor, con Antonio, tirados en el suelo, mirando los bajos de la mesa para confirmar su autenticidad.

Al poco tiempo, debido a su preocupación por el Castillo de San Romualdo y su historia, fue enviado especial al Castillo de Susa, al norte de Africa, a comprobar y observar, como se habían conservado, igualmente, el uso que se le había dado a dicho castillo. Vino encantado.

Guardo las fotografías y videos grabados por él, y la belleza, y utilidad que, en principio, queríamos dar a nuestro castillo, parecido al de su hermano gemelo de la ciudad antes citada.

Quisiera, desde aquí, hacer un reconocimiento, tanto institucional como personal, en agradecimiento que debe tener nuestra ciudad hacia la persona de Antonio.

Podría escribir innumerables actuaciones, como su participación en la organización, y luego en sus publicaciones de las Jornadas Arqueológicas, que tanto, en su momento, dieron que hablar y que recogían las inquietudes de tantísimas personas y entidades que encontraban en estas semanas un punto de reunión para exponer sus ideas y trabajos acerca de nuestra historia.

No quisiera terminar sin reconocer el trabajo realizado en la digitalización de las fotografías del patrimonio y del archivo de Joaquín Quijano. Verdadera historia en imágenes del último siglo de nuestra ciudad.

Muchas gracias Antonio, por todo y por tanto, un abrazo. 